\title{
Perspectives for an Architecture of Solitude
}

\section{Terryl N. Kinder}

\section{(2) OpenEdition}

\section{Journals}

\section{Édition électronique}

URL : https://journals.openedition.org/cem/811

DOI : 10.4000/cem.811

ISSN : 1954-3093

\section{Éditeur}

Centre d'études médiévales Saint-Germain d'Auxerre

\section{Édition imprimée}

Date de publication : 15 août 2005

ISSN : 1623-5770

\section{Référence électronique}

Terryl N. Kinder, «Perspectives for an Architecture of Solitude », Bulletin du centre d'études médiévales d'Auxerre | BUCEMA [En ligne], 9 | 2005, mis en ligne le 08 novembre 2006, consulté le 22 septembre 2022. URL : http://journals.openedition.org/cem/811; DOI : https://doi.org/10.4000/cem.811

Ce document a été généré automatiquement le 22 septembre 2022.

\section{(c) (i) (2)(2)}

Creative Commons - Attribution - Pas d'Utilisation Commerciale - Partage dans les Mêmes Conditions 4.0 International - CC BY-NC-SA 4.0

https://creativecommons.org/licenses/by-nc-sa/4.0/ 


\title{
Perspectives for an Architecture of Solitude
}

\author{
Terryl N. Kinder
}

1 Perspectives for an Architecture of Solitude. Essays on Cistercians, Art and Architecture in Honour of Peter Fergusson, ed. Terryl N. Kinder, co-edition Cîteaux : Commentarii cistercienses (series Studia et Documenta 13) and Brepols (series Medieval Church Studies 11), Brecht - Turnhout, 2004.

2 The thirty-four essays in this volume range from a discussion of the earliest Christian legislation on art (fourth century) to an account of a garden project of 1811 designed to efface all previous monastic habitation at Pontigny. Between these chronological signposts are studies on the design, siting, building, and archaeology of churches, infirmaries, abbots' lodgings, gatehouses, private chambers, grange chapels and the life lived within and around them. They treat of the complexities of building and rebuilding; of architectural and artistic adaptations to place, period and political upheaval; of the interrelationship of text and structure; and of the form, iconography and influence of some of the great cathedrals and churches of the Middle Ages. Geographically, the papers range from the British Isles through Spain, France, Flanders, and Germany to the centre of the medieval world: Jerusalem. This is a wide-ranging and authoritative collection of studies which is essential reading for any historian of medieval - especially Cistercian - art and architecture. 